\title{
Assessment of long-term variation in displacement for a GPS site adjacent to a transition zone between collision and subduction
}

\author{
David Ching-Fang Shih $\cdot$ Yih-Min Wu • \\ Gwo-Fong Lin · Jyr-Ching Hu $\cdot$ Yue-Gau Chen · \\ Chien-Hsin Chang
}

Published online: 17 April 2007

(C) Springer-Verlag 2007

\begin{abstract}
A transition and subduction zone adjacent to the Ryukyu Arc, Ryukyu Trench, and Okinawa Trough, extends between southern Japan and northeastern Taiwan. It is generated during the northwestward subduction of the Philippine Sea Plate, which lies the Eurasian Plate along the Ryukyu Trench. The movement of the Philippine Sea Plate is hindered at the northeastern corner of Taiwan, which causes complicated structure of the Philippine Sea Plate at the western end of the Ryukyu subduction zone. Development of the active subduction and transition boundary near the western Ryukyu Arc is evaluated statistically by using displacements derived from GPS site data. The statistical model shows that the absolute displacement derived from GPS measurements of nearly 8 years indicates a maximum spatial variation of $0.625 \mathrm{~m}$. Three trends are observed for such long-term progress, and use of linear regression also reveals quite good consistency between the data and statistic models. Such rate is also elevated following the trend development. Southeastern and nearly horizontal movement is suggested to the main
\end{abstract}

D. C.-F. Shih · Y.-M. Wu · J.-C. Hu · Y.-G. Chen

Department of Geosciences, National Taiwan University,

Taipei 10617, Taiwan

G.-F. Lin

Department of Civil Engineering, National Taiwan University,

Taipei 10617, Taiwan

D. C.-F. Shih $(\square)$

Institute of Nuclear Energy Research, AEC, P.O. Box 3-7, Lungtan 32546, Taiwan, ROC

e-mail: cfshih@iner.gov.tw

C.-H. Chang

Central Weather Bureau, Taipei 10048, Taiwan development of for the site movements, it is likely related to the tensional activity adjacent to this boundary.

Keywords GPS · Uncertainty - Statistics - Ryukyu Arc · Taiwan

\section{Introduction}

Taiwan lies about $150 \mathrm{~km}$ east the Fukien coast of the mainland China, separated from the latter by the Taiwan Strait (Fig. 1). Taiwan Province is comprised of 81 islands and islets. Geographically, Taiwan Province is represented by the main island with 13 islands and scattered islets. Taiwan is a member of the Ryukyu-Taiwan-Luzon arc chain rimming the western border of the Pacific Ocean (Fig. 2). The tectonic evolution of Taiwan can be attributed either to the development of classic geosynclinal cycles or to the interaction of crustal plates. In the geosynclinal model, Taiwan is formed by a typical mobile or organic Cenozoic geosynclinal deposition on a pre-Tertiary metamorphic basement filled with Tertiary sediments to a thickness of more than $10,000 \mathrm{~m}$. In the plate tectonic model, the main island of Taiwan is situated on the junction between the continental Eurasian Plate on the west and the oceanic Philippine Sea Plate on the east. Taiwan can thus be divided into two major geologic or tectonic provinces, separated by a linear and narrow fault-bounded valley that marks the collision suture of the two converging plates (Ho 1982).

Knowledge of the major tectonic features and structural elements of this particular island chain is essential for interpretation of the plate tectonic evolution of Taiwan. The important structural elements in this region are the Asian continent, Ryukyu Arc, Luzon Arc, South China Sea, 
Fig. 1 Map showing studied GPS site and schematic tectonic boundaries (Google 2006)

Fig. 2 Schematic model showing continent-arc collision and plate tectonic setting of Taiwan (redraw after, Angelier et al. 2001)
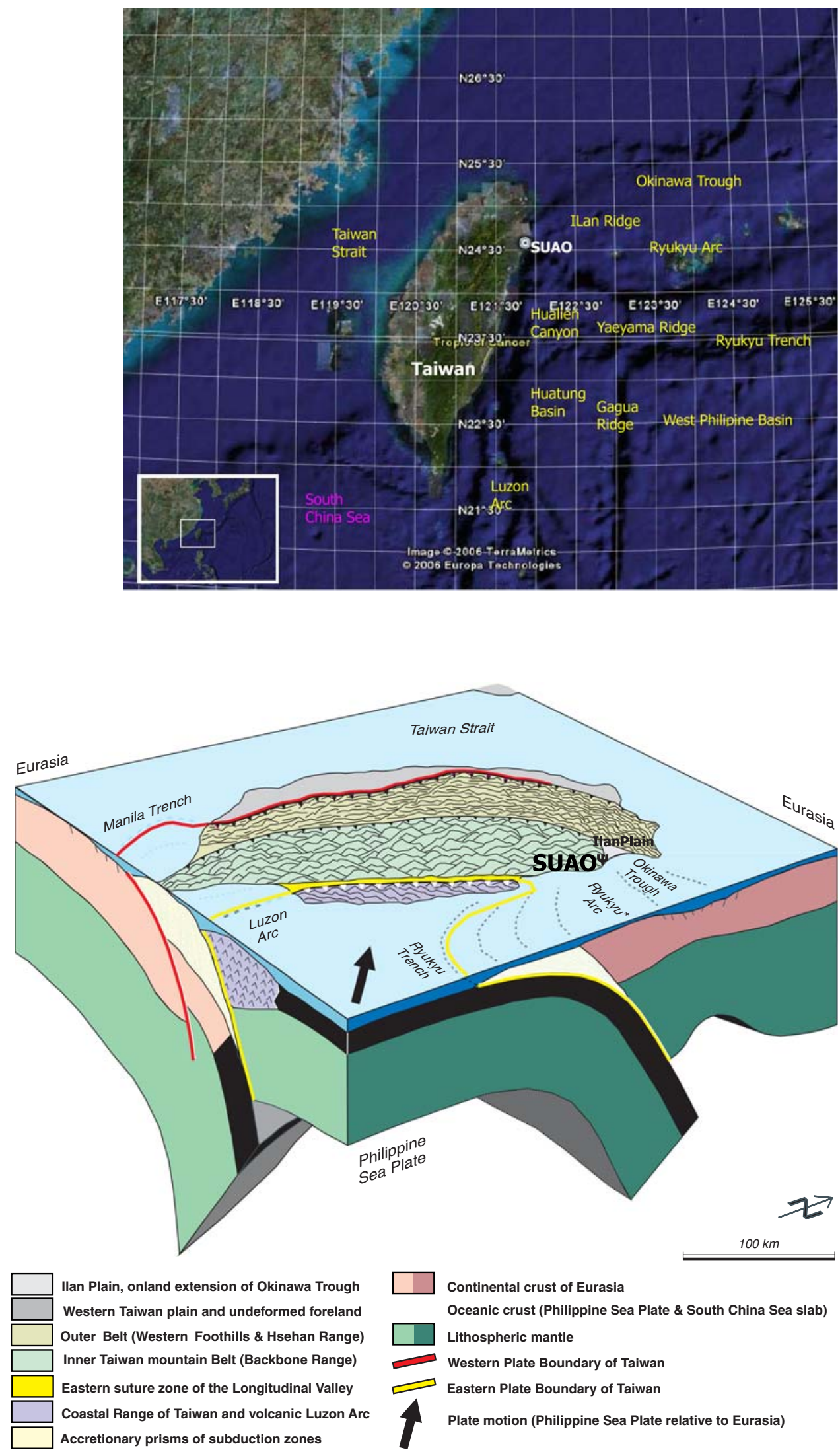
Fig. 3 Active and extent plate boundaries in Taiwan-Luzon region (redraw after,

Malavieille et al. 2002)

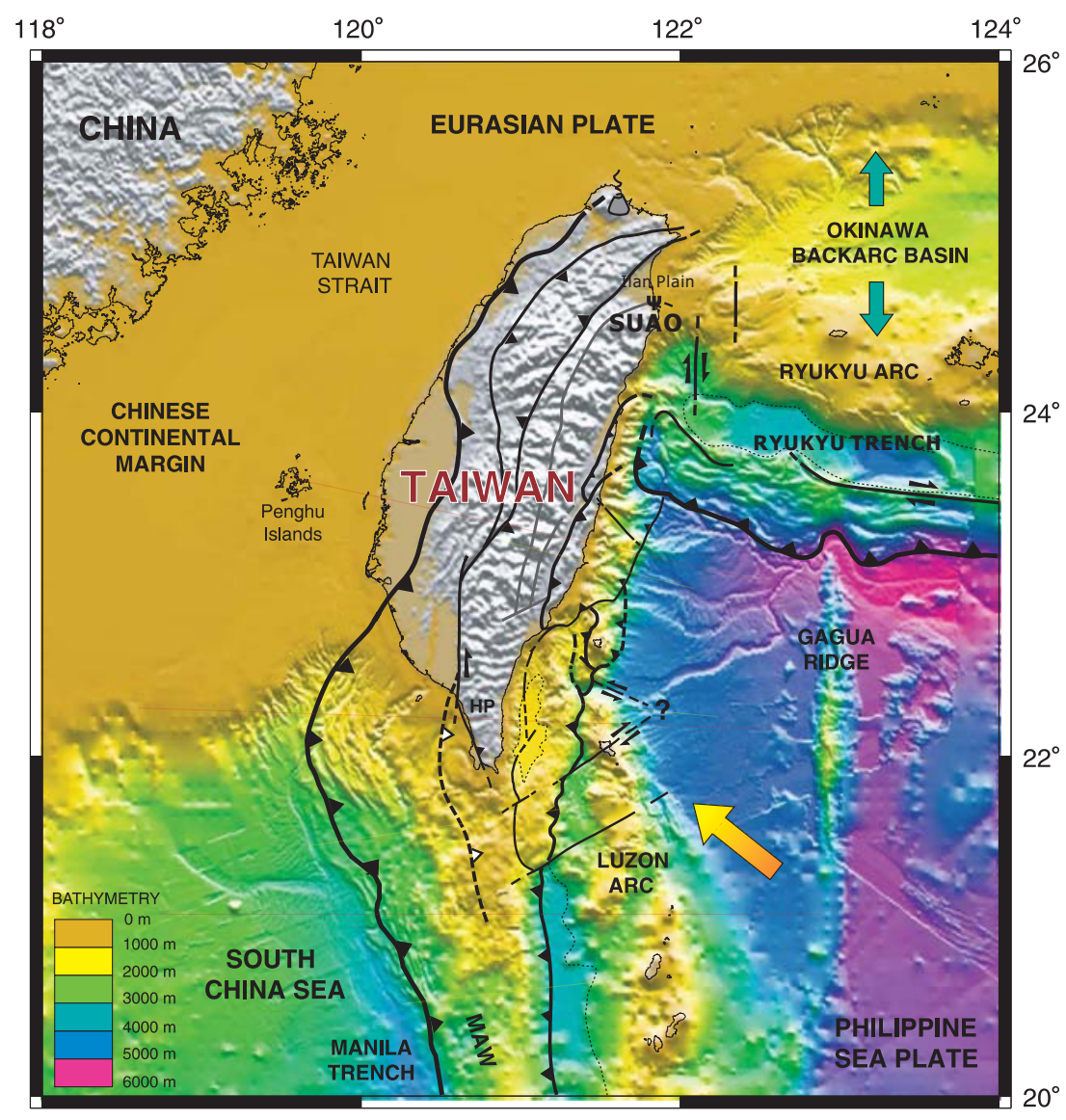

Fig. 4 Seismicity activities near the studied site. Spatial scatter of seismic events show that a boundary-related distribution is demonstrated near the studied area

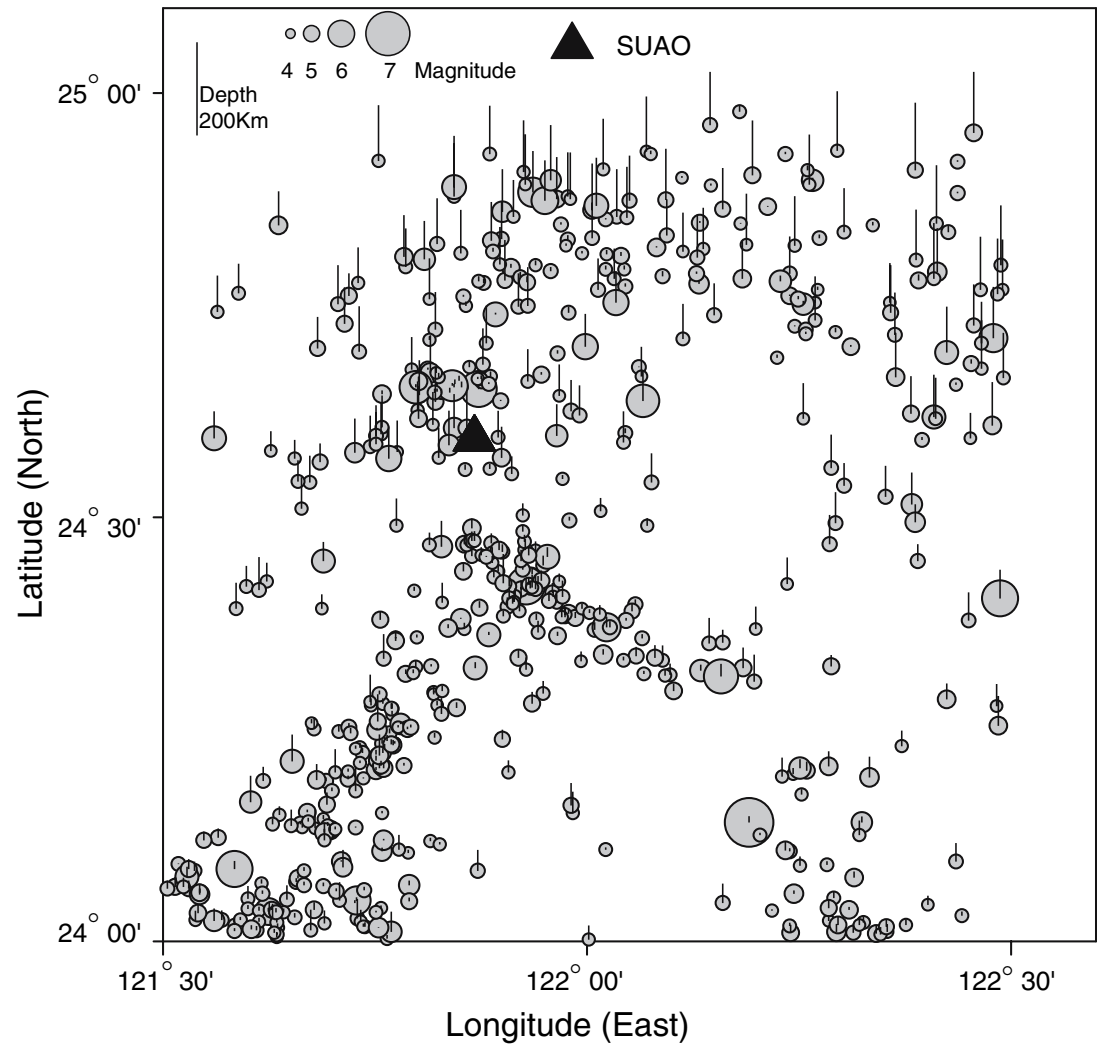


and Philippine Sea Basin. Among them are three major marginal basins, which are the South China Sea, Philippine Sea Basin, and Okinawa Trough behind the Ryukyu Arc. The Ryukyu Arc system is situated on the southeast of the East China Sea continental slope of the East China Sea and includes from north to south, Okinawa Trough, Ryukyu Ridge, and Ryukyu Trench, respectively. This island arc joins the northeastern part of Taiwan and tectonic units of the Ilan Plain and its related volcano group. The Okinawa Trough is located inside of the Ryukyu Arc and is a marginal sea or an extensional of the back-arc basin (Bowin et al. 1978). The western extension of the trough is the Ilan Plain in northeastern Taiwan. From the theory of lithospheric plate tectonics or new global tectonics, Taiwan is situated at a convergent and compressive boundary between two major tectonic plates, resulting from an active collision of an island arc (the Luzon Arc on the edge of Philippine Sea Plate) with the continental margin of Asia (on the Eurasian Plate). The collision is a very young tectonic event and the present rate of plate convergence is estimated about $7 \mathrm{~cm} /$ year in a northwest-southeast direction (Seno 1977) (Fig. 3). Using seismicity as well as other geophysical and geological data in the Taiwan region, Wang et al. (2001) have investigated the lithospheric structure of the Philippine Sea Plate beneath the western end of the Ryukyu subduction zone and its tectonic effects. A geodynamic model developed by Sibuet and Hsu (2004) addressed the notion of a continuum from subduction to collision, traces of the Miocene volcanic arc, and plate activity adjacent to this transition area.
The main objective of this study is to realize possible development in the current status near this active plate boundary area using long-term statistical assessment of position variation measured from GPS site. A major early implementation of GPS was in the study of ground trust. Aircraft are used to photograph areas on the Earth's surface. Index marks are often surveyed on the ground to provide reference locations on these photographs, which can assist in determining their scale and orientation; GPS can be used to survey these locations. Based on its characteristics, high positional accuracy is expected from GPS survey measurements. This research uses data of geodetic coordinate to identify the uncertainty of site position from the viewpoint of the spatial and temporal location, or the nature of environmental changes. Displacement derived by GPS is processed by the Bernese software (Bernese 2006); the average root-mean-square (rms) values of residuals for all stations were used to correct after removing the coseismic offsets and, periodic variations. Residual value is can be taken as the tolerating precision of continuous GPS measurement. A statistical method (Cressie 1993; Hann 1977) is available to characterize the three components of a geodetic coordinate, which are longitude, latitude, and height. Regression analysis is also used to evaluate trends in position. Spatial scatter of seismic events has shown that, more or less, a boundary-related distribution is demonstrated near this transition area (Fig. 4). Resultant statistical significance infers the possible cause of variations may be due to the nature of seismic events which often occur in conjunction with tectonic activity.

Table 1 Descriptive statistics for the position displacement obtained from GPS

\begin{tabular}{|c|c|c|c|c|c|c|c|}
\hline & Size & Missing & Mean & Stan & ard deviation & Standard error & C.I. of mean \\
\hline East & 2,268 & 0 & 0.1710 & 0.13 & & 0.00276 & 0.00542 \\
\hline North & 2,268 & 0 & -0.2350 & 0.14 & & 0.00309 & 0.00606 \\
\hline Altitude & 2,268 & 0 & -0.0241 & 0.02 & & 0.00053 & 0.00104 \\
\hline \multirow[t]{2}{*}{ Displacement } & 2,268 & 0 & 0.2950 & 0.19 & & 0.00406 & 0.00797 \\
\hline & Range & Maximum & \multicolumn{2}{|r|}{ Minimum } & Median & $25 \%$ & $75 \%$ \\
\hline East & 0.454 & 0.4090 & \multicolumn{2}{|r|}{-0.0452} & 0.1800 & 0.0409 & 0.2830 \\
\hline North & 0.482 & 0.0004 & \multicolumn{2}{|r|}{-0.4820} & -0.2610 & -0.3560 & -0.0940 \\
\hline Altitude & 0.237 & 0.0654 & \multicolumn{2}{|r|}{-0.1720} & -0.0263 & -0.0424 & -0.0055 \\
\hline \multirow[t]{2}{*}{ Displacement } & 0.625 & 0.6250 & & 0.0000 & 0.3210 & 0.1040 & 0.4560 \\
\hline & Skewness & Kurtosis & \multicolumn{2}{|c|}{$\mathrm{K}-\mathrm{S}$ distance } & K-S probability & Sum & Sum of squares \\
\hline East & 0.10400 & -1.391 & \multicolumn{2}{|l|}{0.1250} & $<0.001$ & 388.155 & 105.669 \\
\hline North & -0.00174 & -1.411 & \multicolumn{2}{|l|}{0.1270} & $<0.001$ & -532.505 & 174.164 \\
\hline Altitude & 0.03150 & 0.555 & \multicolumn{2}{|l|}{0.0405} & $<0.001$ & -54.589 & 2.758 \\
\hline Displacement & 0.06700 & -1.416 & \multicolumn{2}{|l|}{0.1350} & $<0.001$ & 669.593 & 282.592 \\
\hline
\end{tabular}



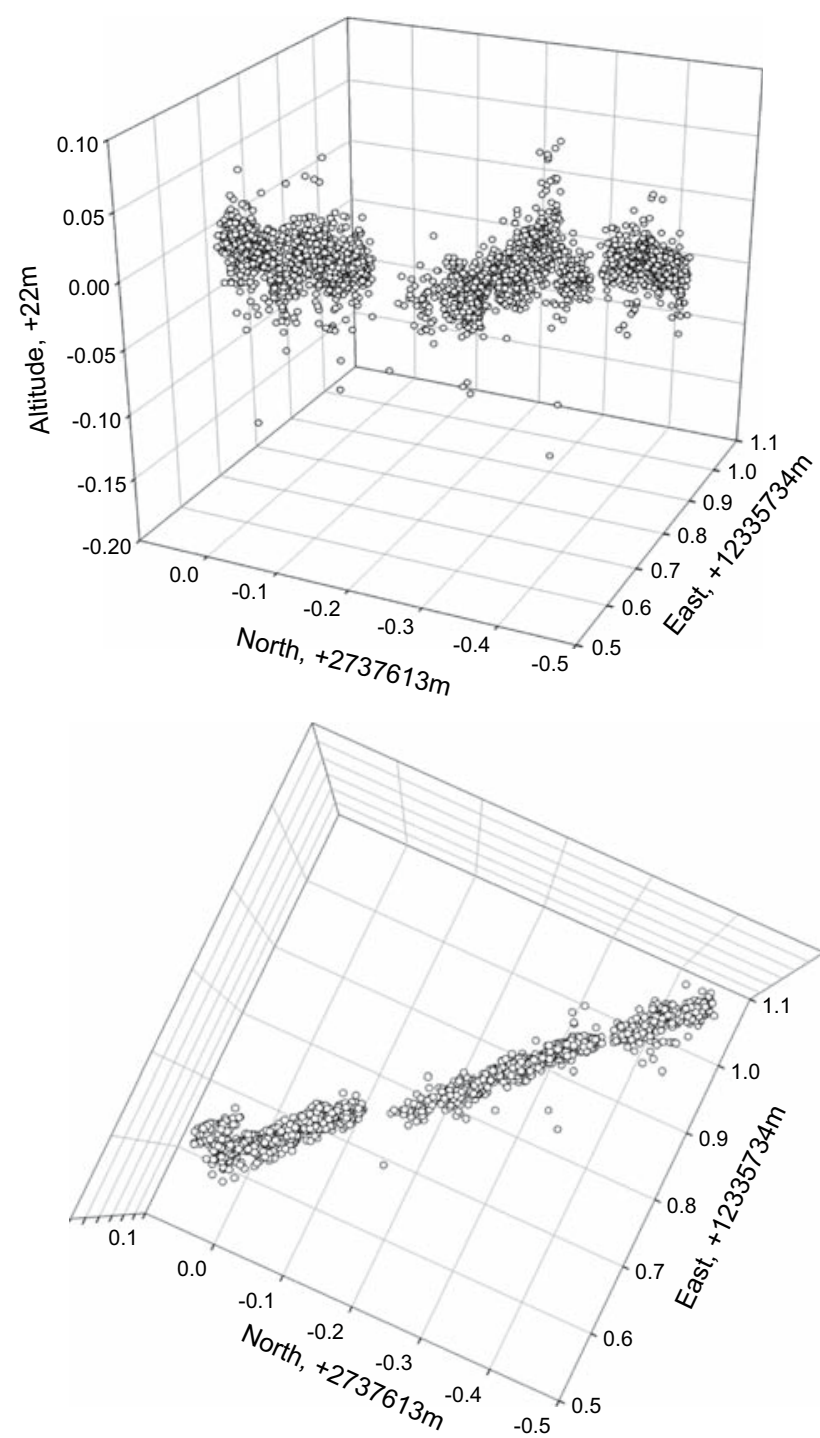

Fig. 5 Position obtained from GPS for SUAO station. A total of 2,268 discontinuous daily GPS data are collected over nearly 8 years. Deviation and absolute displacement of the longitude, latitude, and height components are referred to 1 January 1999

\section{Conceptual model of studied site}

The study site is located at Suao (SUAO station), the northeastern corner of Taiwan with a coordinate of

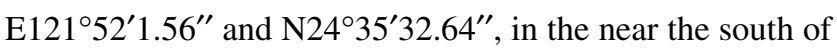
Ilan Plain (Fig. 1). The Ilan Plain is a triangular shape along the northeastern coast of Taiwan, facing the Pacific Ocean. The two other sides are fringed by high mountains composed mainly of Miocene to Paleogene slate (Ho 1982). Each side of this triangular plain has a length of about $30 \mathrm{~km}$ and the total area is nearly $320 \mathrm{~km}^{2}$. By tectonic analysis, the Ilan Plain marks the western termination of the Okinawa Trough, which extends from Japan towards the north end of Taiwan. The extensional opening

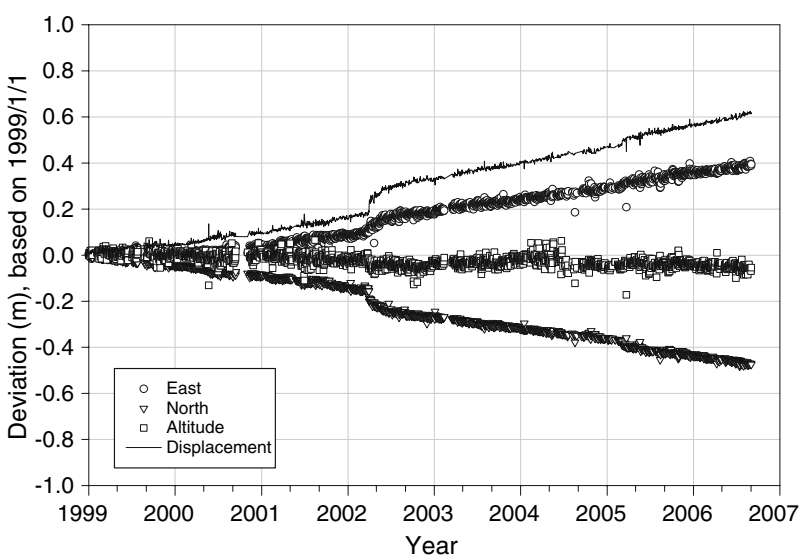

Fig. 6 Time series of position components and displacement at SUAO station. It shows that a linear trend is progressively increased and reveals two jumps in March 2002 and May 2005, respectively

of the Okinawa Trough thus projects westward into Taiwan to form the Ilan Plain. The pre-Tertiary metamorphic complex is the oldest geologic-tectonic element of Taiwan and constitutes the basement of the Tertiary fold-and thrust belts of western Taiwan. Various basement rocks are exposed extensively along the eastern flank of the Central Range and form the eastern margin of the Eurasian Plate. All of these rocks were deformed and altered principally during the late Mesozoic orogenesis so that this tectonic unit is termed the Mesozoic tectonized basement of Taiwan. This metamorphic belt is in a north-south trend with length of $250 \mathrm{~km}$ and varies in width from $30 \mathrm{~km}$ in the north to about $10 \mathrm{~km}$ on the south. All the metamorphic rocks in the basement complex are grouped under the general stratigraphic term "Tananao Schist", (Yen 1954a, b; 1960). The GPS site at SUAO is constructed on this basement rock. As can be expected, local sloping or subsidence is ignored. A total of 2,268 discontinuous daily GPS data have been collected at SUAO over nearly 8 years (Table 1; Fig. 5). Time series for the longitude, latitude, and height components of deviation and absolute displacement are referred to 1 January 1999.

\section{Quantitative analysis}

The data shows that a linear trend is progressively increased and reveals two jumps in March 2002 and May 2005, respectively (Fig. 6). Three sections of trend variation, i.e., trend 1, 2 and 3, are marked for the statistical modeling. Descriptive statistics first quantitatively is used to analyze the displacement for the three directional components of GPS data (Table 1). Deviation of three position components of GPS data is observed to maintain in the eastern and southern direction with downward displace- 

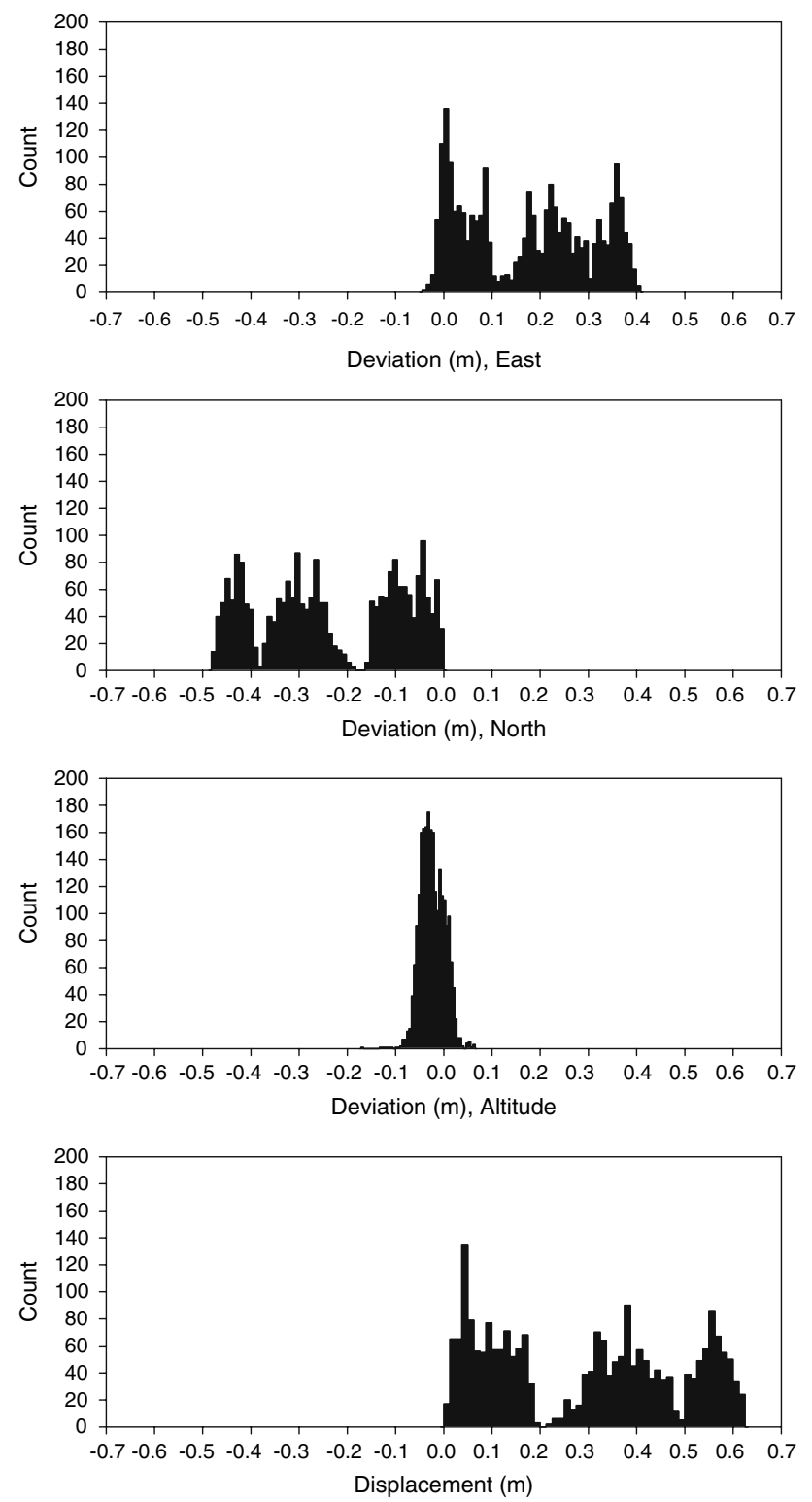

Fig. 7 Histogram of position components and displacement at SUAO station. It indicates that the combination of deviation in the east and the south likely dominate absolute displacement

ment. Absolute displacement is then computed from these components and demonstrates a maximum range of $0.625 \mathrm{~m}$. Three obvious groups of the histogram indicate that the combination of deviation in the east and the south likely dominate absolute displacement (Fig. 7). A normality test is used to establish a centralized histogram for altitude deviation. That test fails, which indicates that the data varies significantly from the pattern expected for a normal population distribution. Median and 75th-percentage values show that the error for estimating position with the GPS is less than $1 \mathrm{~cm}$ for all components (Table 2). Note that the north-south component manifests the least
Table 2 Descriptive statistics for the error of GPS positioning

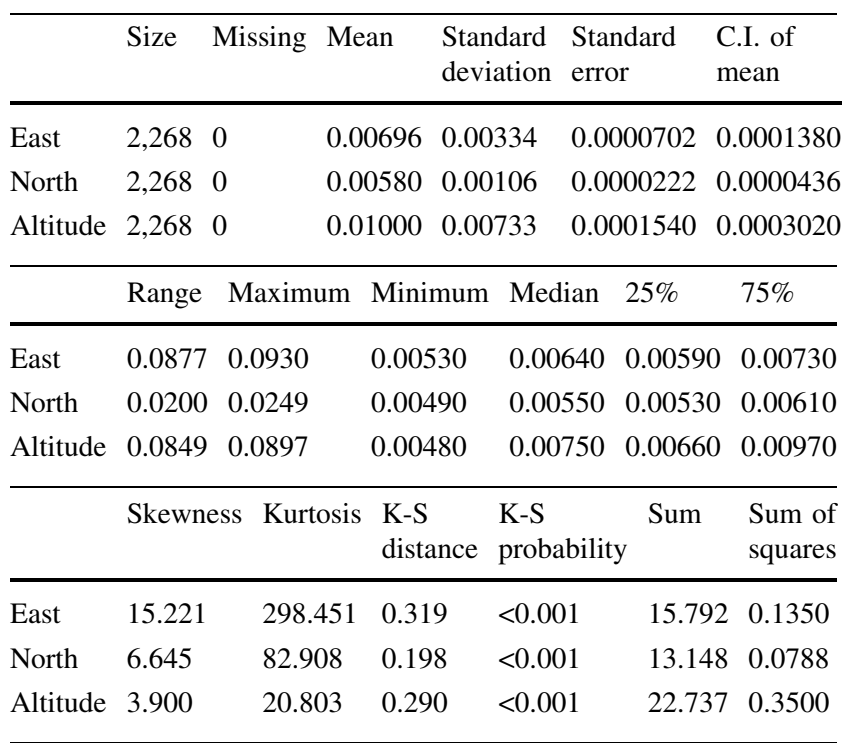

variation, while the error of altitude is more uncertain (Fig. 8). First-order linear regression is conducted to demonstrate the association of absolute displacement and
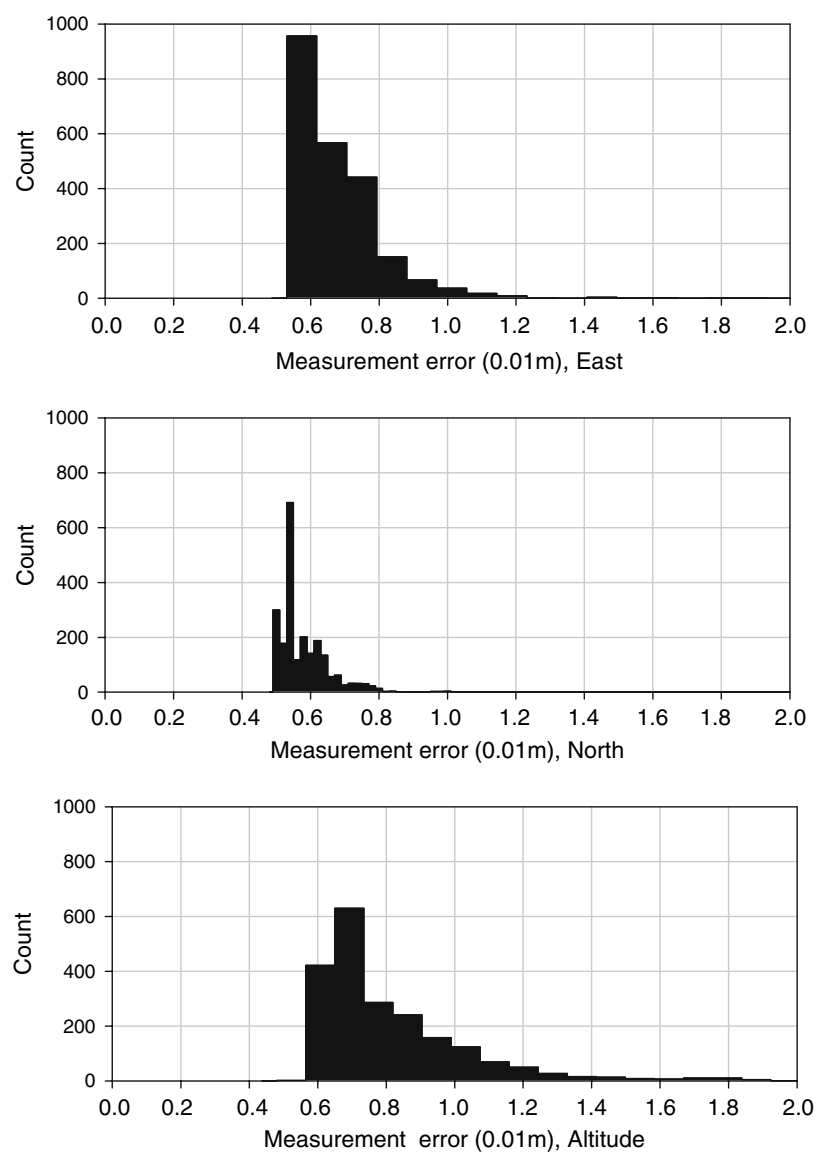

Fig. 8 Histogram of the positioning error derived from GPS at SUAO station 
Fig. 9 Analysis of linear regression for the displacement at SUAO station
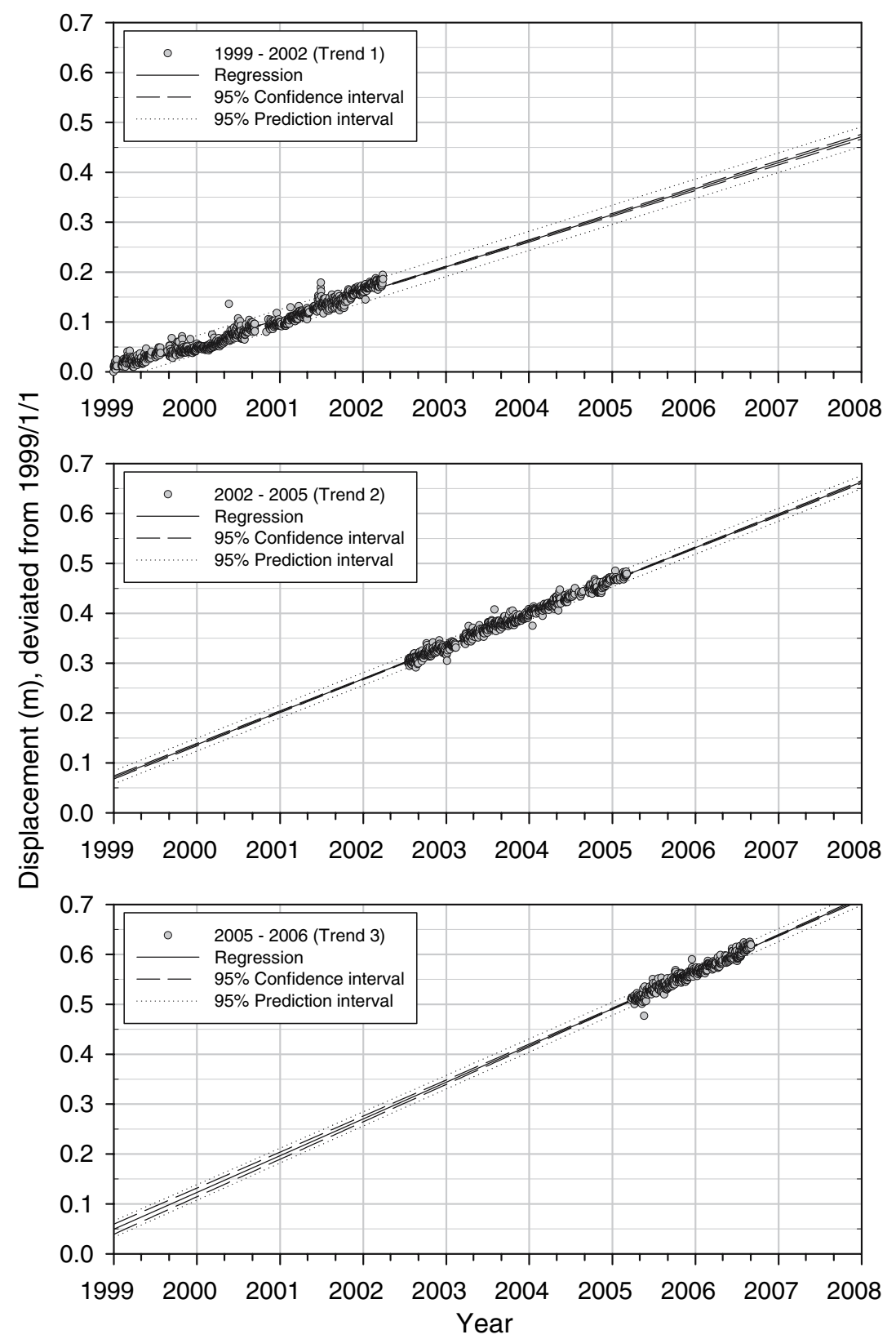

time frame (Fig. 9). Regression statistics are modeled for three time periods (Table 3). Table 3 shows that regression parameters $\left(y_{0}, a\right)$ intercept and slope for displacement versus date is analyzed with very high $R^{2}$, adjusted- $R^{2}$ value and $t$-statistic. Good consistency is thus established between the regression model and the observed displacement. Note also that the increasing rate $(a)$ represents an increase on the order of $10^{-4} \mathrm{~m} /$ day from trend Sect. 1-3.

\section{Discussion}

Daily displacement derived from GPS data for approximately 8 years of data are quantitatively analyzed and summarized. The results show that GPS displacement of each of the three components is less than one half meter. The resultant absolute displacement represents a maximum value of $0.625 \mathrm{~m}$. An outline of absolute displacement versus seismic event with focal depth is demonstrated on Fig. 10. There are two jumps of absolute displacement shown, which are also accompanied by a multitude of seismic events at shallow depths, i.e., less than $20 \mathrm{~km}$, especially for March 2002 and March 2005. By determining horizontal and vertical angle from the displacement components, it is found that the mean absolute displacement of trend 1 is aimed at $E 73.5^{\circ} \mathrm{S}$ with a mean vertical angle upward by $1^{\circ}$ (Table 4 ). Note that the trend 2 and trend 3 are concentrated on the mean 
Table 3 Regression analysis for the position displacement

\begin{tabular}{|c|c|c|c|c|c|c|}
\hline \multicolumn{7}{|c|}{ Linear regression $y=y_{0}+a t$, where $t$ in day and deviated from $1 / 1 / 1999$} \\
\hline & \multicolumn{2}{|l|}{ Trend 1} & \multicolumn{2}{|l|}{ Trend 2} & \multicolumn{2}{|l|}{ Trend 3} \\
\hline Date range & \multicolumn{2}{|c|}{$1 / 1 / 1999-30 / 3 / 2002$} & \multicolumn{2}{|c|}{$17 / 7 / 2002-5 / 3 / 2005$} & \multicolumn{2}{|c|}{$24 / 3 / 2005-2 / 9 / 2007$} \\
\hline $\begin{array}{l}\text { Regression } \\
\text { parameter }\end{array}$ & $y_{0}$ & $a$ & $y_{0}$ & $a$ & $y_{0}$ & $a$ \\
\hline $\begin{array}{c}\text { Number of } \\
\text { data }\end{array}$ & 947 & & 717 & & 490 & \\
\hline Value & $1.65 \times 10^{-3}$ & $1.43 \times 10^{-4}$ & $7.09 \times 10^{-2}$ & $1.80 \times 10^{-4}$ & $4.94 \times 10^{-2}$ & $2.02 \times 10^{-4}$ \\
\hline $\begin{array}{l}\text { Standard } \\
\text { error }\end{array}$ & $6.55 \times 10^{-4}$ & $9.21 \times 10^{-7}$ & $1.58 \times 10^{-3}$ & $9.01 \times 10^{-7}$ & $5.17 \times 10^{-3}$ & $2.03 \times 10^{-6}$ \\
\hline$t$-Statistic & 2.522 & 155.268 & 44.979 & 200.058 & 9.557 & 99.118 \\
\hline$P$ value & 0.012 & $<0.001$ & $<0.001$ & $<0.001$ & $<0.001$ & $<0.001$ \\
\hline $\begin{array}{l}\text { Correlation } \\
\text { coefficients } \\
(R)\end{array}$ & 0.981 & & 0.991 & & 0.976 & \\
\hline$R^{2}$ & 0.962 & & 0.982 & & 0.953 & \\
\hline Adjusted $R^{2}$ & 0.962 & & 0.982 & & 0.953 & \\
\hline $\begin{array}{l}\text { Standard } \\
\text { error of } \\
\text { estimate }\end{array}$ & 0.010 & & 0.007 & & 0.007 & \\
\hline
\end{tabular}
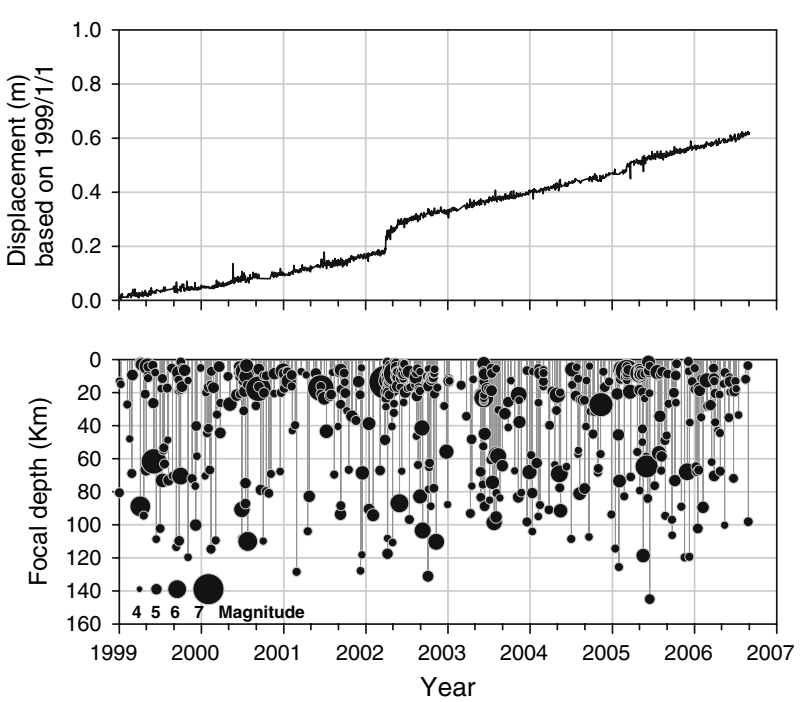

Fig. 10 Comparison for the time series of displacement and seismicity activities shown on Fig. 4

direction of $\mathrm{E} 54^{\circ} \mathrm{S}$ to $\mathrm{E} 51^{\circ} \mathrm{S}$ and are nearly horizontal with a small downward angle of $4-5^{\circ}$ (Table 4; Fig. 11). Furthermore, Kurtosis, K-S distance and K-S probability do not support passing the normality test at these orientation angles. The folded rocks of the Ryukyu Arc are connected with the fold belt of southern Japan to the northeast and extend southeastward into Taiwan. There is a remarkable contrast on the north and south of the Ryukyu Arc (Eguchi and Uyeda 1982). Only the south-

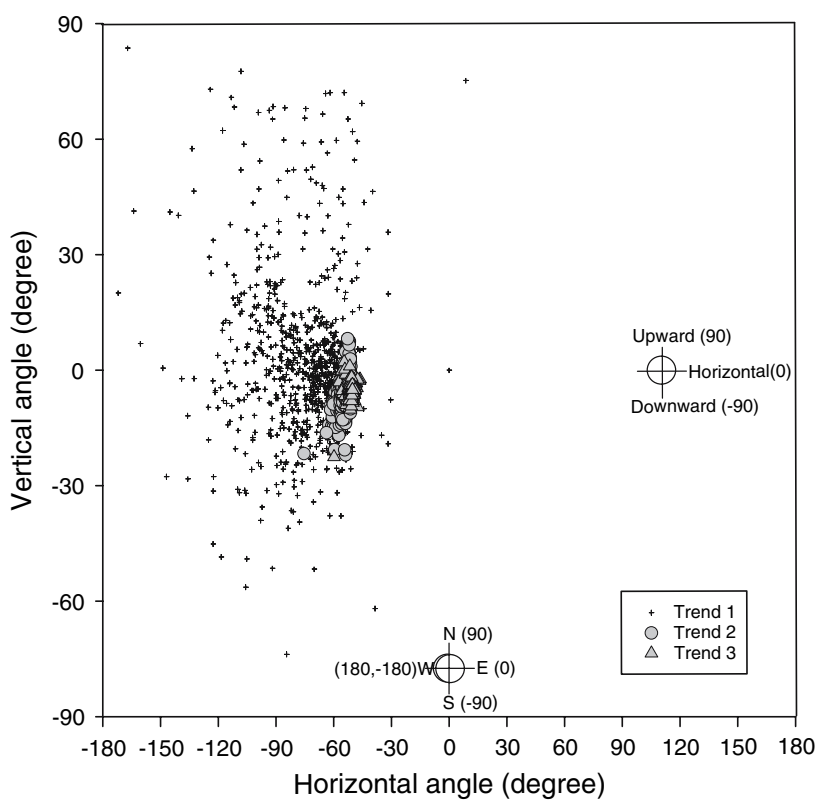

Fig. 11 Vertical and horizontal angle of displacement demonstrated in the observed trends

western end of the Ryukyu Arc system is related to the tectonic study of the Taiwan region. The western end of the non-volcanic arc in the Ryukyu Arc is interpreted as connected to the east-turning segment of the Central Range in Taiwan (Biq 1981). The Ryukyu Trench situated southeast of the Ryukyu Ridge is one of the deepest portions of Pacific Ocean, and demonstrates an active 
Table 4 Descriptive statistics for the orientation of position displacement

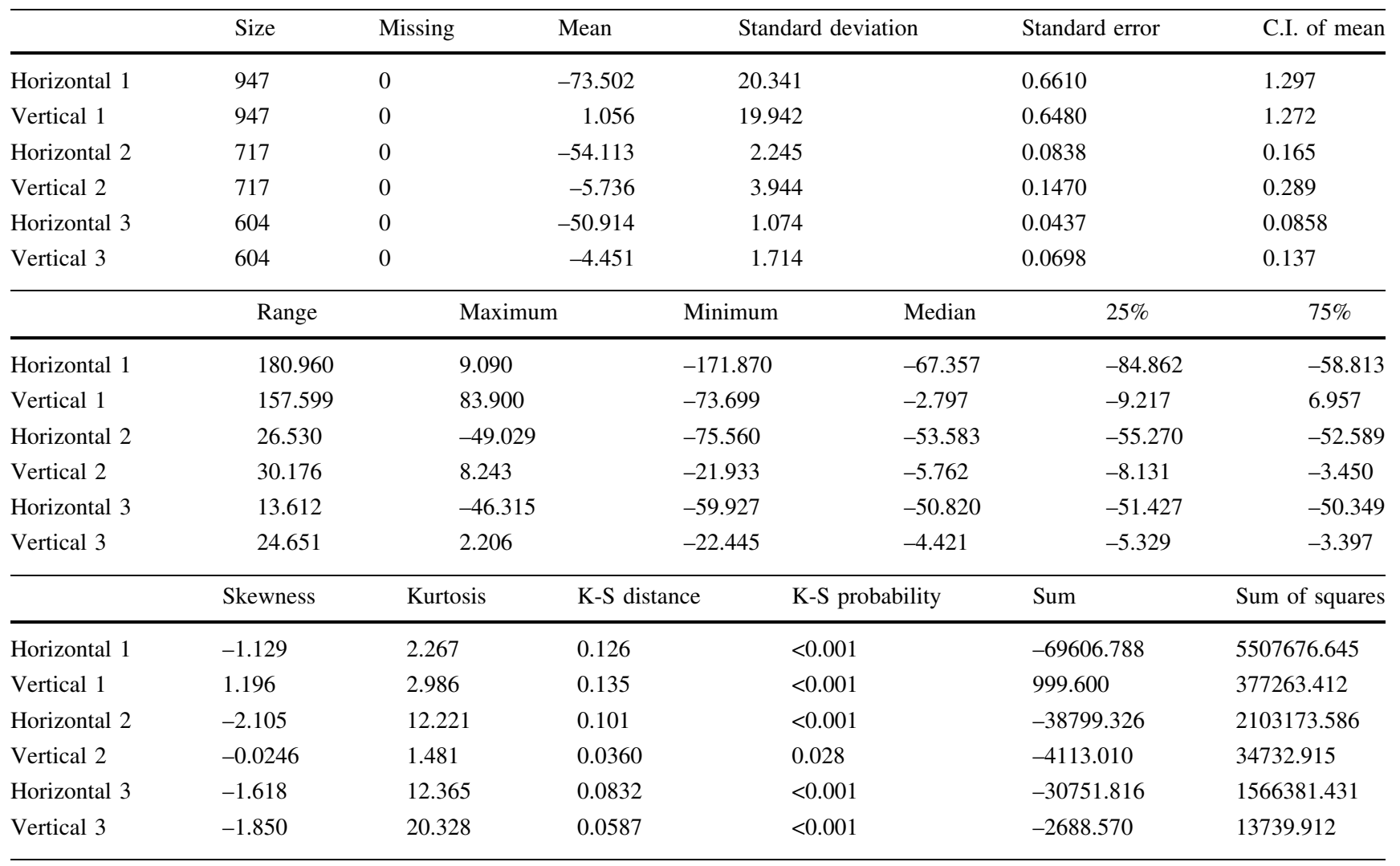

Orientation in angle (degree)

1 Trend 1;2 Trend 2; 3 Trend 3

subduction zone. The existence of a major strike-slip zone under the ocean between Taiwan and the Ryukyu Arc is postulated by Wageman et al. (1970) and Wu (1970). A western boundary of the lithosphere exists beneath Taiwan. The boundary almost lies along the $121^{\circ} \mathrm{E}$ meridian line (Wang et al. 2001). The boundary is migrating westward at a rate of about $6 \mathrm{~cm} /$ year along with the movement of the Philippine Sea Plate. The westward migration of the lithospheric boundary of the plate causes the westward extension of the Okinawa Trough, which lags behind Philippine Sea Plate by about 600,000 years. The initial stage of the Okinawa Trough formation, in turn, put the whole northern Taiwan area under tensional stress (Wang et al. 2001). It is apparent that absolute displacement toward the southeast is possibly on account of tensional activity in this boundary. Unfortunately, spatial coherence along the boundary cannot be assessed due to deficient data for the same period for other GPS stations. Nevertheless, this study provides a useful statistical model to effectively assess daily displacement by GPS observation. Although consistent spatial variation can only be derived for the SUAO station, the data shows that the resultant variation is likely related to tectonic activity in this boundary. However, in the future more spatial coherence data is needed to make reliable inferences.

\section{Conclusions}

Development of an active subduction and transition boundary near the western Ryukyu Arc has been assessed statistically by displacements obtained from a GPS site at Suao, Taiwan. In general, intermittent daily displacement quantitatively summarizes the temporal and spatial variations. This method for analyzing the variation of GPS position can be regarded as an effective approach to detect activity along a ground or spatial boundaries. The conclusions of this research are as follows:

1. The results show that absolute displacement derived by a GPS site for nearly 8 years of intermittent daily movements represents a maximum value of $0.625 \mathrm{~m}$ in spatial variation.

2. Three linear trends are concluded for such long-term evolution using time series and histogram analysis. 
Result of linear regression reveals consistency between the data and statistic model. Regression analysis also shows an increasing rate on the order of $10^{-4} \mathrm{~m} /$ day for such movements. This rate is elevated following the trend development.

3. The 75th-percentage value of population demonstrates that the error in estimating position is less than $1 \mathrm{~cm}$ for all components of movement. It did not influence the result of these studies.

4. Southeastern and nearly horizontal movement with very small angle is believed to result from the proposed as the main development of for the site movements; it is likely related to the tensional activity adjacent to this boundary.

5. Moreover, in the future more spatial coherence from GPS data can be used to address more reliable assessments about such activity adjacent to this transition zone.

Acknowledgments This research was supported by the Central Weather Bureau, National Science Council and Institute of Nuclear Energy Research (AEC) of Taiwan, the Republic of China.

\section{References}

Angelier J, Lee J-C, Chu H-T, Hu J-C, Lu C-Y, Chan Y-C, Lin, T-J, Font Y, Deffontaines B, Tsai Y-B (2001) Le Séisme de Chichi (1999) et sa place dans l'orègene de Taiwan. Comptes Rendus de 1'. Académie des Sciences Paris, Sciences de la Terre et des Planèges 333, 5-21

Biq C (1981) Collision, Taiwan-style. Mem Geol Soc 4:91-102
Bowin C, Lu R-S, Lee C-S, Schouten H (1978) Plate convergence and accretion in Taiwan-Luzon region. Bull Am Assoc Petrol Geol 62(9):1645-1672

Bernese (2006) Bernese GPS software. http://www.bernese.unibe.ch/ Cressie NAC (1993) Statistics for spatial data. Wiley, New York

Eguchi T, Uyeda S (1982) Seismotectonics of the Okinawa Trough and Ryukyu Arc. Mem Geol Soc 5

Google (2006) Google Earth. http://earth.google.com

Hann CT (1977) Statistical methods in hydrology. IOWA State University

Ho C-S (1982) Tectonic evolution of Taiwan. The Ministry of Economic Affairs, Republic of China

Malavieille J, Lallemand SE, Dominquez S, Deschamps A, Lu C-Y, Liu C-S, Schnürle P (2002) Arc-continent collision in Taiwan: new marine observations and tectonic evolution. In: Byrne TB, Liu C-S (eds) Geology and geophysics of an arc-continent collision, Taiwan. The Geological Society of America special paper 358, pp 187-211

Seno T (1977) The instantaneous rotation vector of the Philippine Sea Plate relative to the Eurasian plate. Tectonophysics 42:209-226

Sibueta JC, Hsu S-K (2004) How was Taiwan created? Tectonophysics 379:159-181

Wageman JM, Hilde TWC, Emery KO (1970) Structural framework of East China Sea and Yellow Sea. Bull Am Assoc Petrol Geol 54(9):1611-1643

Wang C-S, Chuang S-W, Li M-L, Cheng W-B (2001) Lithospheric structure of Philippine Sea Plate near the western end of Ryukyu subduction zone and some of its tectonic effects. Terrestrial Atmos Ocean Sci (Suppl S)287-304

Wu F-T (1970) Focal mechanisms and tectonics in the vicinity of Taiwan. Bull Am Assoc Petrol Geol 60(6):2045-2056

Yen T-P (1954a) The gneisses of Taiwan. Bull Geol Surv Taiwan 5:1-100

Yen T-P (1954b) The green rocks of Taiwan. Bull Geol Surv Taiwan $7: 1-46$

Yen T-P (1960) A stratigraphic study of the Tananao Schist in northern Taiwan. Bull Geol Surv Taiwan 12:53-66 